\title{
Cluster Analysis of Inbound Tourist Source Market in Guangdong Province
}

\author{
YU Tong \\ He Yuan Polytechnic, He Yuan, Guangdong, China \\ email: 86282557@qq.com
}

\begin{abstract}
According to the data of inbound tourism in Guangdong Province from 2006 to 2015, the author analyzes the development situation and composition of inbound tourism in Guangdong Provinceby Excel software, and the author conducts cluster analysis of inbound tourism market of Guangdong Province by SPSS23.0 software. The results show that the inbound tourism has strong development momentum, and the inbound tourism market has showed diversified characteristics. According to the results of the cluster analysis, the inbound tourism market of Guangdong Province is divided into four categories. Based on the analysis and evaluation, it is proposed to develop the Asian market stably, develop the Western European and North American markets energetically and explore the Russian market actively.
\end{abstract}

Keywords: Guangdong Province, inbound tourism, market, SPSS, cluster analysis

\section{Introduction}

Inbound tourism is an important part of the tourism market, which has been in the status of "rapid development" among the three major Chinese tourism markets and has made important contribution to strengthening foreign exchange and increasing foreign exchange earnings. In order to fully understand the development situation of inbound tourism in Guangdong Province, the author chooses 16 major source countries of Guangdong inbound tourism as the research objects. According to relevant data of "Guangdong Statistical Yearbook" (2007-2016), the author analyzes the development situation and composition of inbound tourism in Guangdong Provinceby Excel software, and conducts cluster analysis of inbound tourism market of Guangdong Province by SPSS23.0 software, which means to provide the basis for the development of inbound tourism in Guangdong Province.

\section{The Development Situation of Inbound Tourism Market in Guangdong Province}

Guangdong Province is located in the southeast coast of China, which is an economically developed province in China. Over the years, GDP gross has been ranked first among the provinces and cities in China. As a result of economic development, Guangdong attracts a large number of foreigners to invest and operate business, foreign commerce and trade activities are very active. Guangdong has a 
warm climate, pleasant environment, beautiful natural scenery, diversified Lingnan culture and unique conditions for the development of tourism.Every year, there are many foreigners come to take a holiday. Therefore, Guangdong a big inbound tourism province in China, the major indicators such as the number of inbound tourists and international tourism foreign exchange earnings have been ranked first in China.

According to the statistical data of inbound tourism market in Guangdong province, Excel software is used to draw the change trend of the number of inbound tourists and tourism foreign exchange income in Guangdong province from 2006 to 2015 (Figure 1). It can be seen from Figure 1 that, the development trend of the number of inbound tourists and tourism foreign exchange income in Guangdong province on the whole showed a steady growth trend from 2006 to 2015. Among them, the number of inbound tourists in 2011 and 2013 showed a slight decline trend, but the next year would rebound, and the number of inbound tourists increased from5.2466 million in 2006 to 7.8183 million in 2015 , an increase of $49.02 \%$; international tourism foreign exchange income showed a continuous upward trend, which increased from 7.53 billion US dollars in 2006 to 17.885 billion US dollars in 2015, an increase of $137.52 \%$. According to data released by the China National Tourism Administration, there were 25.985 million foreign inbound tourists in China in 2015, and the international tourism foreign exchange income was 113.65 billion US dollars ${ }^{[1]}$. The proportion of Guangdong was $30.09 \%$ and $15.74 \%$ respectively. The above data showed that the inbound tourism industry in Guangdong province showed a strong momentum of development, effectively promoting the development of tourism industry in Guangdong province.
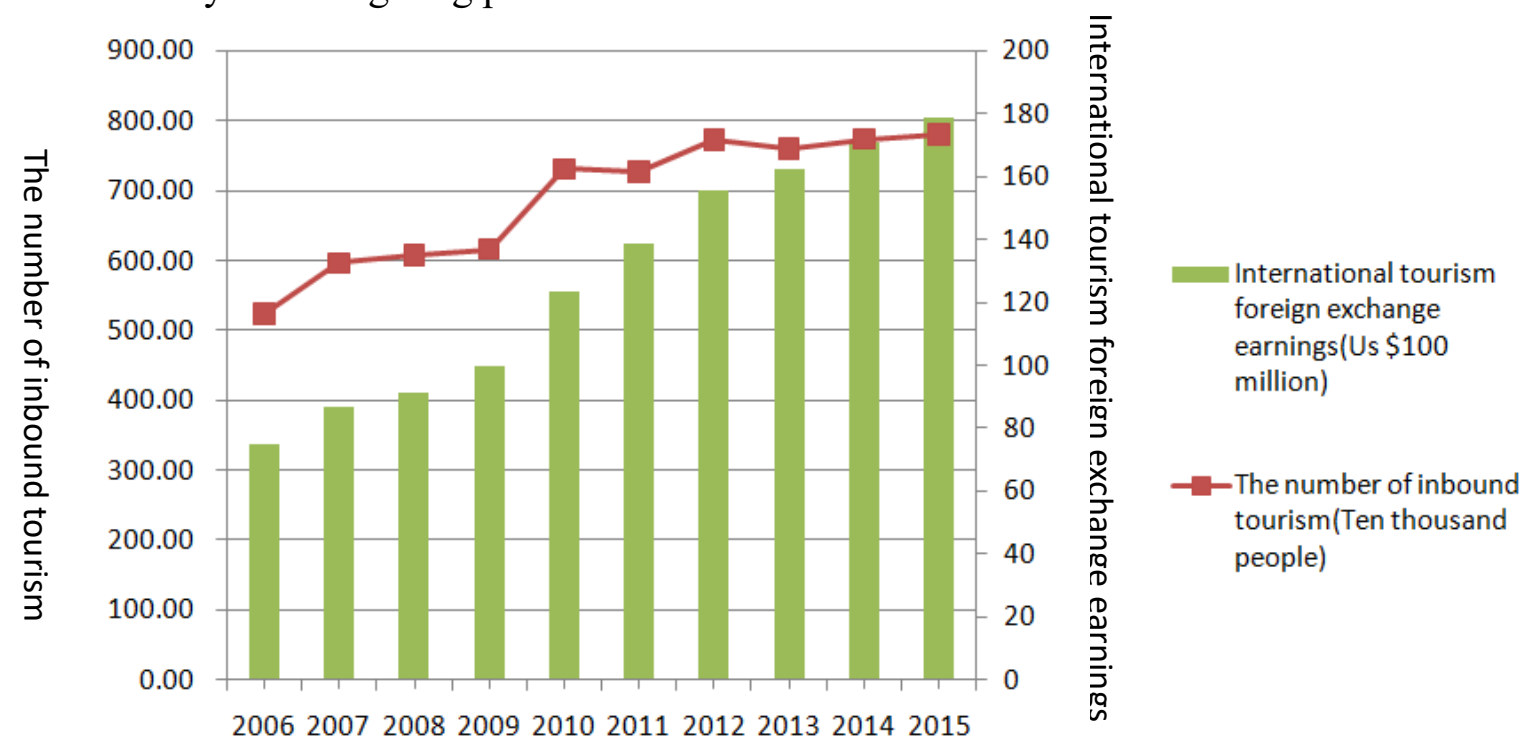

Figure 1. the change trend of the number of inbound tourists and tourism foreign exchange income in Guangdong province from 2006 to 2015

\section{Analysis of Inbound Tourism Market Structure of Guangdong Province}

The number of inbound tourists is mainly determined by the distance between the source country and the destination country ${ }^{[2]}$. Japan, South Korea and countries of 
Southeast Asia in Asia are relatively close to China, thus the number of inbound tourists is relatively large. On the contrary, Europe and the United States are relatively far from China, thus the number of inbound tourism is relatively small. According to Table 1, it can be calculated that the total number of inbound tourists from 7 countries in Asia is 2.3298 million in 2015, which accounts for $59.08 \%$ of the total number of the inbound tourists from major source countries and has an obvious advantage; the total number of inbound tourists from 9 countries outside Asia is 1.6138 million, accounting for $40.92 \%$ of the total number of inbound tourists from major source countries.

It can be seen from Table 1 that, Japan has been the first largest source country of inbound tourism in Guangdong province. However, the number showed a shock downward trend, which decreased from 1.0775 million in 2006 to 0.8924 million in 2015 , an reduction of $17.18 \%$ over the ten years. As the second largest source country of inbound tourism in Guangdong, the United States had an opposite trend towards Japan and showed a steady upward trend, which rose from 0.4778 million in 2006 to 0.7108 million in 2015 , an increase of $48.77 \%$. The trend of South Korea was similar to the United States, South Korea was the third largest source country of inbound tourism in Guangdong province from 2006 to 2008, but it was surpassed by Malaysia during the period of 2009-2013. After 2014, due to the decline in the number of Malaysian inbound tourists, South Korea became the third largest source country again. Among the 10 countries, 12 of them achieved increase of the number of inbound tourists. Russia increased by $134.72 \%$ which was the largest proportion. Japan, Thailand, Indonesia and Italy showed negatively growth. Among them, Italy had the largest decline of $61.41 \%$.

It can be seen from Figure 2 that, in 2015, the market share of 16 major source countries of Guangdong inbound tourism only occupied $50.44 \%$, just over half. Other countries accounted for $49.56 \%$, indicating that the source of source countries of Guangdong inbound tourism in Guangdong was scattered,inbound tourism market of Guangdong showed diversified characteristics.The scattered source of source countries can avoid the risk, which is conducive to the stability of the inbound tourism market $^{[3]}$.

Table 1. the number of Guangdong inbound tourists from major source countries from 2006 to 2015

Unit: ten thousand people

\begin{tabular}{|c|r|r|r|r|r|r|r|r|r|r|}
\hline $\begin{array}{c}\text { Year } \\
\text { source } \\
\text { countries }\end{array}$ & 2006 & 2007 & 2008 & 2009 & 2010 & 2011 & 2012 & 2013 & 2014 & 2015 \\
\hline Japan & 107.75 & 128.03 & 85.72 & 99.36 & 107.73 & 112.96 & 115.67 & 112.08 & 100.78 & 89.24 \\
\hline $\begin{array}{c}\text { South } \\
\text { Korea }\end{array}$ & 26.51 & 40.08 & 32.49 & 32.8 & 41.81 & 39.32 & 42 & 45.48 & 48.13 & 47.45 \\
\hline Philippines & 3.59 & 3.87 & 3.33 & 4.29 & 4.72 & 5.41 & 5.68 & 7.54 & 7.67 & 5.96 \\
\hline Singapore & 20.36 & 24.56 & 19.8 & 25.05 & 28.48 & 30.29 & 30.46 & 33.82 & 30.8 & 28.52
\end{tabular}


Table 1, cont.

\begin{tabular}{|c|r|r|r|r|r|r|r|r|r|r|}
\hline Thailand & 17.23 & 17.41 & 13.02 & 12.58 & 13.43 & 13.05 & 13.92 & 16.73 & 17 & 14.75 \\
\hline Indonesia & 14.24 & 16.17 & 12.84 & 12.42 & 15.89 & 15.32 & 19.83 & 21.93 & 19.89 & 11.87 \\
\hline Malaysia & 25.61 & 35.32 & 29.21 & 34.05 & 42.16 & 41.41 & 43.22 & 49.43 & 42.32 & 35.19 \\
\hline $\begin{array}{c}\text { The United } \\
\text { States }\end{array}$ & 47.78 & 58.32 & 45.19 & 54.37 & 64.58 & 65.19 & 66.48 & 64.57 & 63.36 & 71.08 \\
\hline Canada & 9.14 & 12.48 & 9.41 & 10.76 & 13.31 & 12.01 & 11.6 & 12.95 & 12.32 & 13.3 \\
\hline $\begin{array}{c}\text { The United } \\
\text { Kingdom }\end{array}$ & 13 & 14.62 & 11.21 & 12.58 & 13.84 & 14.05 & 14.66 & 16.99 & 17.2 & 14.7 \\
\hline France & 9.94 & 12.28 & 9.68 & 10.7 & 11.99 & 12.93 & 13.2 & 15.68 & 15.36 & 14.88 \\
\hline Germany & 13.92 & 12.91 & 9.37 & 10.06 & 11.83 & 13.03 & 12.78 & 13.98 & 13.67 & 14.23 \\
\hline Italy & 20.34 & 9.18 & 6.65 & 8.13 & 8.65 & 8.92 & 9 & 9.53 & 7.29 & 7.85 \\
\hline Russia & 3.6 & 4.17 & 3.83 & 4 & 5.86 & 6.87 & 8.29 & 12.13 & 12.82 & 8.45 \\
\hline Australia & 11.24 & 13.89 & 11 & 13.77 & 14.98 & 15.1 & 13.7 & 16.23 & 15.65 & 13.82 \\
\hline $\begin{array}{c}\text { New } \\
\text { Zealand }\end{array}$ & 1.86 & 2.48 & 1.62 & 2.29 & 2.41 & 2.44 & 2.69 & 3.11 & 3.03 & 3.07 \\
\hline
\end{tabular}

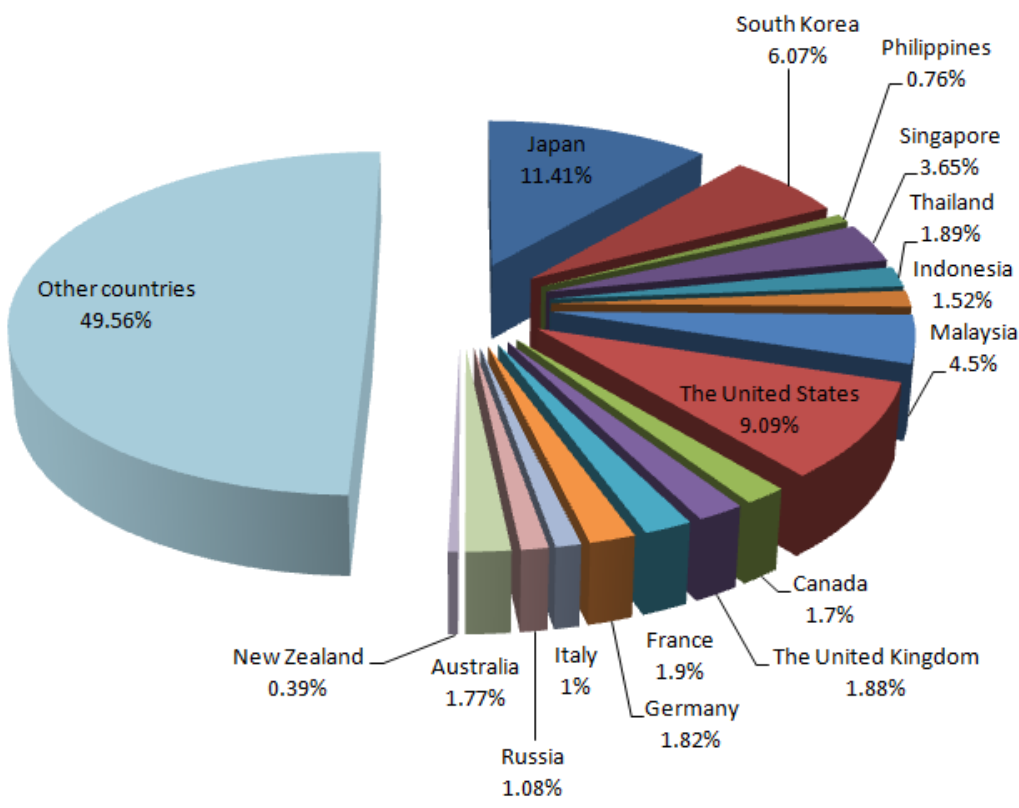

Figure 2. source country market share of Guangdong inbound tourism in 2015

\section{Cluster Analysis of Inbound Tourism Market of Guangdong Province}

Cluster analysis is a method of classifying data based on the information of the data ${ }^{[4]}$. In the SPSS software, cluster analysis is divided into three methods, 
includinghierarchical clustering, fast clustering and two-stage clustering. In this paper, the author uses hierarchical clustering method. According to the data in Table 1, the author assumes X1 = Japan, X2 $=$ Korea, X3 = Philippines, X4 = Singapore, X5 = Thailand, X6 = Indonesia, X7 = Malaysia, X8 = X12 = Germany, X13 = Italy, X14 = Russia, X15 = Australia, X16 = New Zealand. The author conducts hierarchical clustering analysis by using SPSS23.0 software and draws the tree diagram of cluster analysis of inbound tourism market in Guangdong province.

It can be seen from Figure 3 that, Guangdong inbound tourism market can be divided into four categories from 2006 to 2015, Japan as a class, the United States as a class, Korea and Malaysia and Singapore as a class, the United Kingdom, Australia, Thailand, France, Germany, Canada, Indonesia, Italy, the Philippines, Russia and New Zealand as a class. Japan and the United States has been the first and second largest source country of Guangdong inbound tourism respectively, measures need to be taken to consolidate Japan market and the US market. South Korea, Malaysia and Singapore are the most promising tourist markets in Guangdong Province, and should be actively developed. The development of inbound tourism of most of Europe and the United States and Oceania countries is slow, and the intensity of development needs to be enhanced and this part of market needs to be actively expanded.

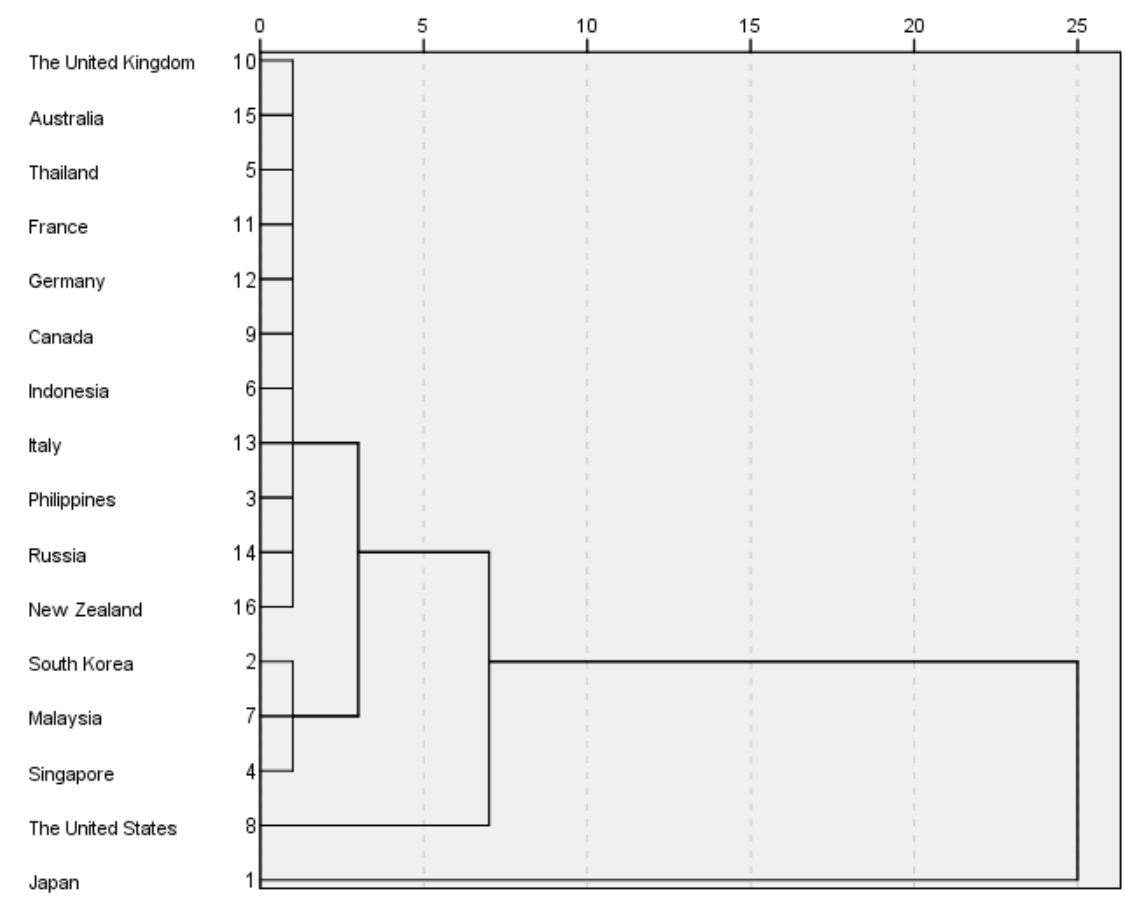

Figure 3. Tree diagram of cluster analysis of Guangdong inbound tourism market.

\section{Conclusion and Suggestions}

\subsection{Conclusion}

The inbound tourism industry of Guangdong province has a strong momentum of development, and the inbound tourism market shows diversified characteristics. The results of cluster analysis show that the main tourist markets of Guangdong inbound tourism are divided into four categories: Japan as a class, the United States as 
a class, South Korea and Malaysia and Singapore as a class, and other countries as a class.

\subsection{Suggestions to stably develop the Asian market.}

Asian countries that take Japan and South Korea as the representativesis the largest market of Guangdong inbound tourism. We should focus on the development of business tourism, study tourism, search-origin tourism, religious tourism and hot spring tourism. We should vigorously develop the Lingnan cultural tourism products and natural landscape leisure tourism products, increase the tourism propaganda of mainstream media in the source countries, actively participate in local tourism fairs, so as to improve the visibility of Guangdong tourism products.

\section{To Vigorously Develop the Western European and North American Markets.}

Western Europe and North American countries have developed economy, which are the world's major tourist source export areas, the development of the regional market can greatly enhance the international status and prestige of Guangdong tourism. Constraints on the tourist sourceof the region is due to the reason that the distance is far and the tourism cost is high. According to the high income of the regional tourists, we should focus on develop high-end commercial tourism, vacation tour, golf tourism, cruise and yacht tourism, adventure tourism and other projects, so as to adapt to the personalized travel needs of European and American markets.

\section{To Actively Explore the Russian Market.}

In recent years, Russia is the fastest-growing market of Guangdong inbound tourism. Due to the cold winter in Russia, there is a relatively strong demand for vacation abroad in winter. Guangdong has a warm climate in winter and high-end and complete holiday facilities, which is attractive to the Russian tourists. But Russia is far away from Guangdong, thus we should optimize the traffic conditions, open direct fights or charter flights between major cities in Russia and Guangdong. At the same time, we should carry out targeted propaganda and promotion in the Russian markek $^{[5]}$, so as to improve the awareness and yearning degree of Russian tourists to Guangdong tourism and attract more Russian tourists to travel in Guangdong.

\section{References}

[1] Information on http://www.cnta.gov.cn.

[2] Chen Peng, Wu Ling, Han Chuan-long.Cluster Analysis of Inbound Tourist Market in Anhui Province:Journal of Hebei North University (Social Science Edition). Vol.28(2012), p. 51-55.

[3] Yu Tong. A study on the Temporal and SpatialVariety of Guangdong Inbound Tourism Market :Journal of Huizhou University (Social Science Edition), Vol. 34 (2014), p. 36-40.

[4] Zhang Wentong, Dong Wei:Advanced Tutorial of SPSS Statistical Analysis(Higher Education Press, China 2013).

[5] Guangdong Provincial Tourism Bureau, Guangdong Provincial Tourism Development Research Center: Overall Planning of Guangdong Provincial Tourism Development(2011-2020)( China Travel \&Tourism Press, China 2014). 